\title{
Profil RAPD Tanaman Kantung Semar Beberapa Koleksi Kebun Raya Baturraden
}

\author{
Retno Mayangsari ${ }^{1}$, Agus Hery Susanto $^{1}$, Alice Yuniaty ${ }^{1}$ \\ ${ }^{1}$ Fakultas Biologi Universitas Jenderal Soedirman, Purwokerto \\ E-mail: susanto1408@yahoo.co.id
}

\begin{abstract}
A study on the RAPD profile of some pitcher plants (Nepenthes spp.) of Baturraden Botanical Garden collection was carried out. Seven individuals of particular concern were Mount Slamet semi-endemic and Java endemic species, i.e. N. adrianii and N. gymnampora. Both species of pitcher plants were taken from Baturraden Botanical Garden collection. Samples were then subject to genomic DNA extraction, after which RAPD markers were amplified using PCR technique with ten random primers, i.e. ES10G23, ES10A26, ES10C24, ES10G33, OPA-2, OPA-9, OPA-13, OPB-3, OPB-5 and OPB-7. The results show that the 10 primers produce $43(67.2 \%)$ polymorphic bands and 21 $(32.8 \%)$ monomorphic bands with size ranging from 130 to $1,500 \mathrm{bp}$. OPA-2 and OPB-3 produce highest polymorphism, while ES10G23 and OPA-13 produce most monomorphic bands. Dendogram constructed using UPGMA in MEGA 6.06 shows that at a genetic distance of $18 \%$ two clusters are formed. Both clusters are separated seemingly by geographic location.
\end{abstract}

Key words: pitcher plants, RAPD, Baturraden Botanical Garden

\section{Abstrak}

Telah dilakukan penelitian tentang profil RAPD beberapa tanaman kantung semar (Nepenthes spp.) koleksi Kebun Raya Baturraden.Tujuh individu yang dipelajari merupakan spesies semiendemik Gunung Slamet dan endemik Jawa, yaitu N. adrianii dan N. gymnampora. Sampel kedua spesies kantung semar ini diambil dari koleksi Kebun Raya Baturraden. DNA genomik sampel diekstraksi untuk kemudian digunakan sebagai templat dalam amplifikasi marka RAPD menggunakan teknik PCR dengan 10 primer acak, yaitu ES10G23, ES10A26, ES10C24, ES10G33, OPA-2, OPA-9, OPA-13, OPB-3, OPB-5, dan OPB-7. Hasil penelitian menunjukkan bahwa ke-10 primer tersebut menghasilkan $43(67,2 \%)$ pita polimorfikdan 21 (32,8\%) pita monomorfikdengan ukuran berkisar dari 130 hingga 1.500 bp. OPA-2 and OPB-3 menghasilkan polimorfisme tertinggi, sedangkan ES10G23 dan OPA-13 menghasilkan pita monomorfik terbanyak. Dendogram yang dikonstruksi menggunakan UPGMAdalam MEGA 6.06 memperlihatkan bahwa dua klaster terbentuk pada jarak genetik $18 \%$. Kedua klaster tersebut cenderung dipisahkan oleh lokasi geografi.

Kata kunci: kantung semar, RAPD, Kebun Raya Baturraden

\section{Pendahuluan}

Kantung semar (Nepenthes spp.) merupakan tanaman yang unik jika dilihat dari cara mendapatkan makanan. Saat ini populasi kantung semar di alam diperkirakan makin menurun.Hal ini disebabkan oleh beberapa faktor, seperti kebakaran hutan dan alih fungsi lahan hutan atau semak belukar menjadi kawasan permukiman, perladangan, perkebunan, pertanian, atau pun pertambangan.Pemerintah Indonesia telah menetapkan kantung semar sebagai salah satu spesies tumbuhan prioritas dilindungi karena keberadaannya di alam cenderung terancam punah (Berita Negara Republik Indonesia Nomor 51, 2008).

Sebagai instisusi yang bertanggung jawab atas kegiatan konservasi tanaman, Kebun Raya Baturraden mulai mengembangbiakan tanaman kantung semar agar tetap terjaga populasinya di alam (Puspitaningtyas dan Wawangningrum, 2007). Di antara koleksi Kebun Raya Baturraden terdapat spesies kantung semar semiendemik Gunung Slamet dan endemik Pulau Jawa, yaitu $N$. adrianii dan N. gymnampora. Oleh karena itu, perlu dilakukan kajian lebih lanjut karena potensi dan keunikannya yang tidak ada di tempat lain.

Salah satu pendekatan untuk memperoleh data dasar mengenai spesies kantung semar semiendemik Gunung Slamet dan endemik Pulau Jawa dapat dilakukan melalui karakterisasi secara molekuler menggunakan marka tertentu, misalnya RAPD (random amplified polymorphic DNA). Penelitian ini bertujuan untuk mengetahui profil RAPD dan hubungan kekerabatan genetik kantung semar koleksi Kebun Raya Baturraden.

\section{Metode Penelitian}

Sebanyak tujuh sampel daun kantung semar diperoleh dari rumah kaca Kebun Raya Baturraden. Ketujuh sampel tersebut terdiri atas tiga sampel N.adrianii dan empat sampel $N$. gymnampora. Penelitian dilakukan di Laboratorium Molekuler Fakultas Biologi Universitas Jenderal Soedirman dari Januari hingga Maret 2017. 


\section{Cara Kerja}

1. Isolasi DNA genom (Doyle \& Doyle, 1987)

Bufer CTAB dipanaskan dalam waterbath pada suhu $65^{\circ} \mathrm{C}$ selama 1 jam.Daun kantung semar ditimbang sebanyak 0,5 g, dicuci dengan air mengalir dan disemprot dengan alkohol $70 \%$,dikeringkan dengan kertas tisu, laludigerus sampai halus menggunakan mortardan pestle.Ditambahkan CTAB $1.500 \quad \mu l$, dihomogenkan,lalu ditambahkan $15 \mu \mathrm{l} \beta$ merchaptoetanol dan 0,025 g PVP.Selanjutnya, dilakukan inkubasi dalam waterbath pada suhu $65^{\circ} \mathrm{C}$ selama 1 jam, diikuti dengan sentrifugasi pada kecepatan $12.000 \mathrm{rpm}$ selama 22 menit.Supernatan diambil dan ditambah dengan klorofom:isoamil alkohol sebanyak $800 \mu \mathrm{l}$. Dilakukan sentrifugasi lagi dengan kecepatan $12.000 \mathrm{rpm}$ selama 20 menit. Supernatandiambil dan ditambah dengan amonium asetat dan etanol absolut.Campuran didiamkan pada suhu $4^{\circ} \mathrm{C}$ selama semalam, kemudian disentrifugasi dengan kecepatan $11.000 \mathrm{rpm}$ selama 25 menit.Supernatan dibuang, natan ditambah dengan etanol $70 \%$ sebanyak $750 \mu$ l,lalu disentrifugasi dengan kecepatan 11.000 rpm selama 5 menit. Supernatan dibuang,natan (DNA) dikeringkan, kemudian ditambahdengan $100 \mu \mathrm{l}$ buffer TE.

Pengujian kualitas dan kuantitas DNA hasil isolasi dilakukan dengan cara elektroforesis menggunakan media gel agarosa $1 \%$ dan pengukuran nilai absorbansi menggunakan spektrofotometer nanodrop.

\section{Amplifikasi marka RAPD}

ReaksiPCR dibuat dalam volume total reaksi 12,5 $\mathrm{\mu l}$ yang terdiri atas $6,3 \mu \mathrm{l}$ Kappa PCR mix, $100 \mathrm{ng}$ DNA templat, 0,6 $\mu \mathrm{l}(10 \mu \mathrm{M})$ primer, dan air bebas ion dalam $1 \mathrm{x}$ reaksi. Amplifikasi dimulai dengan pradenaturasi pada suhu $94^{\circ} \mathrm{C}$ selama 3 menit, diikuti 35 atau 45 siklus yang terdiri atas denaturasi pada suhu $94^{\circ} \mathrm{C}$ selama 1 menit, penempelan primer pada suhu $31^{\circ} \mathrm{C}$ atau $32^{\circ} \mathrm{C}$ selama 1 menit, pemanjangan primer pada suhu $72^{\circ} \mathrm{C}$ selama 2 menit. Pemanjangan akhir dilakukan pada suhu $72^{\circ} \mathrm{C}$ selama 8 menit dan penyimpanan dilakukan pada suhu $8^{\circ} \mathrm{C}$. Untuk primer ES10G23, ES10A26, ES10C24, dan ES10G33 digunakan suhu penempelan primer $31^{\circ} \mathrm{C}$, sedangkan untuk primer OPA-2, OPA-9, OPA-13, OPB-3, OPB-5, dan OPB-7 digunakan suhu penempelan primer $32^{\circ} \mathrm{C}$. Reaksi dengan primer ES10C24 menggunakan 35 siklus PCR, sedangkan reaksi dengan sembilan primer lainnya menggunakan 45 siklus PCR.Marka RAPD dimigrasikan pada elektroforesis gel agarosa $2 \%$ dengan tegangan 80 volt dan kuat arus $500 \mathrm{~mA}$ selama 60 menit. Visualisasimarka RAPD dilakukan menggunakan transiluminator

\section{Analisis Dat a}

Pita DNA hasil amplifikasi diskor secara terpisah berdasarkan ada tidaknya fragmen untuk setiap individu menggunakan kode biner.Skor 1 diberikan jika ada fragmen dan skor 0 diberikan jika tidak ada fragmen tanpa memandang intensitasnya.Selanjutnya, dilakukan uji analisis kelompok (cluster analysis) secara hierarchical clustering menggunakan Program MEGA 5 (Tamura et al., 2011) dengan metode UPGMA.Hasilnya ditampilkan dalam bentuk dendrogram.

\section{Hasil dan Pembahasan}

\section{Isolasi DNA genom}

Hasil isolasi DNA genom dapat dilihat pada Gambar 1. Pada gambar tersebut terlihat bahwa DNA genom yang diperoleh relatif cukup baik kualitasnya. Hal ini ditunjukkan oleh intensitas pita elektroforesis yang cukup tinggi.Begitu pula, hasil kuantifikasi menunjukkan tingkat kemurnian yang cukup baik (Tabel 1).

Tabel 1. Hasil uji kuantifikasi sampel DNA genom kantung semar koleksi Kebun Raya Baturraden

\begin{tabular}{ccc}
\hline Sampel & A260/A280 & $\begin{array}{c}\text { Konsentrasi } \\
(\mathbf{n g} / \boldsymbol{\mu L})\end{array}$ \\
\hline A1 & 1.534 & 842 \\
A2 & 2.041 & 647 \\
A3 & 2.247 & 701 \\
G1 & 2.563 & 704 \\
G2 & 2.145 & 838 \\
G3 & 1.896 & 994 \\
G4 & 1.921 & 975 \\
\hline
\end{tabular}

Keterangan :

$\mathrm{A} 1=N$. adrianii Igir Gowok, hutan lindung Baturraden, $\mathrm{A} 2=N$. adrianii hutan lindung Gunung Slamet, $\mathrm{A} 3=N$. adrianii Petak 58, hutan alam Gunung Slamet, $\mathrm{G} 1=N$. gymnampora Petak 3 Bukit Tuban Gunung Bhisma, G2 $=N$. gymnampora Gunung Merbabu, G3 = $N$. gmnampora Gunung Prau Desa Pranten Kecamatan Bawang, G4 = N. gymnampora Petung Kriono Pekalongan, Dieng lereng utara. 


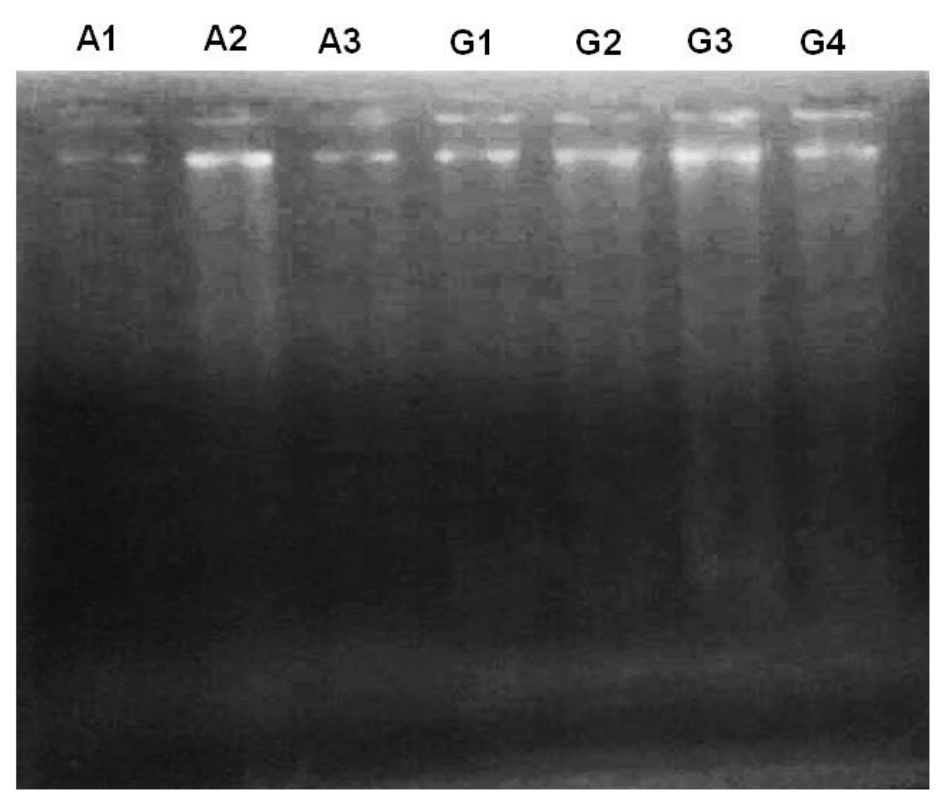

Gambar 1. Elektroforegram hasil ekstraksi DNA genom kantung semar koleksi Kebun Raya Baturraden $(\mathrm{A} 1=N$. adrianii Igir Gowok, hutan lindung Baturraden, $\mathrm{A} 2=N$. adrianii hutan lindung Gunung Slamet, $A 3=$ N. adrianii Petak 58, hutan alam Gunung Slamet,G1 = N. gymnampora Petak 3 Bukit Tuban Gunung Bhisma,G2 $=N$. gymnampora Gunung Merbabu,G3 $=N$. gmnampora Gunung Prau Desa Pranten Kecamatan Bawang,G4 = N. gymnampora Petung Kriono Pekalongan, Dieng lereng utara

\section{Amplifikasi marka RAPD}

Semua primer yang digunakan dapat mengamplifikasi marka RAPD pada DNA kantung semar.Hal ini menunjukkan bahwa semua primer tersebut mempunyai urutan basa nukleotida yang

komplementer dengan kedua untai DNA genom. Menurut Williams (1990), primer akan menempel dengan baik pada DNA templat apabila terdapat komplementasi pada posisi yang berlawanan.
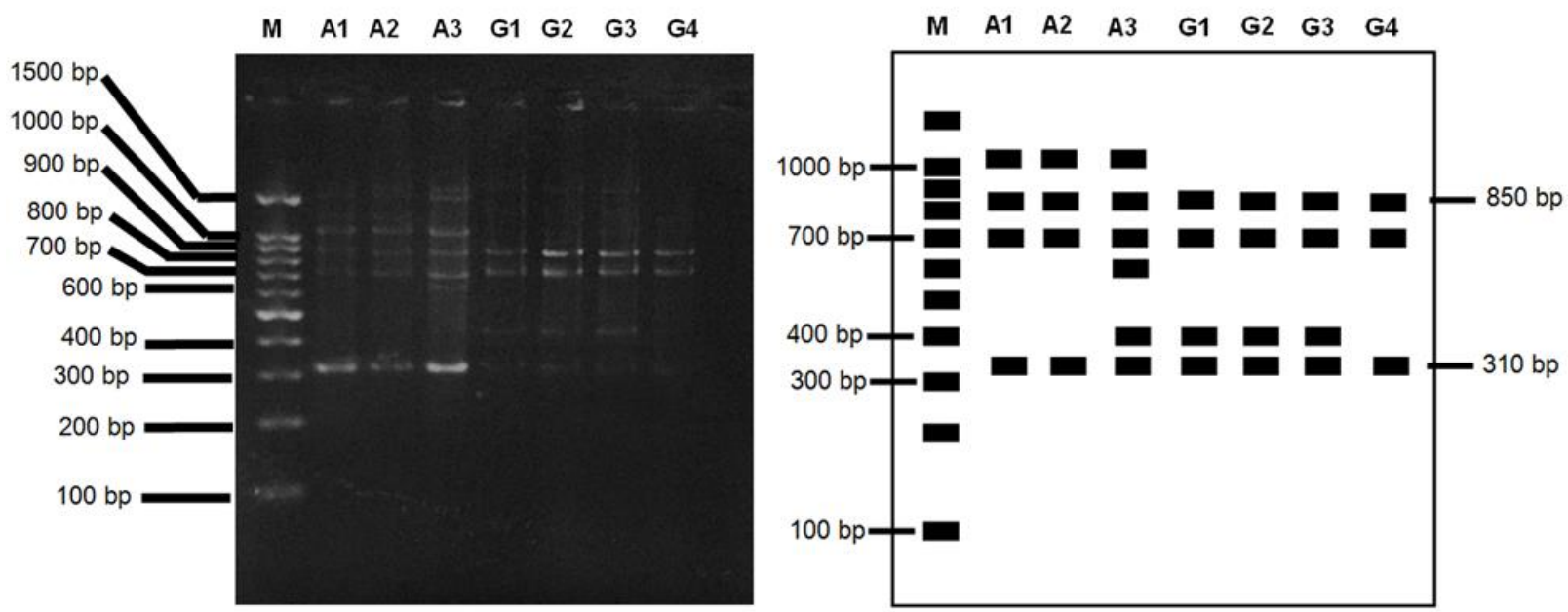

Gambar 2a dan 2b. Hasil dan interpretasi hasil amplifikasi PCR-RAPD menggunakan primer ES10G23 $(\mathrm{M}=\mathrm{DNA}$ marka $1 \mathrm{~kb}, \mathrm{~A} 1=N$. adrianii Igir Gowok, hutan lindung Baturraden, $\mathrm{A} 2=N$. adrianii hutan lindung Gunung Slamet, $\mathrm{A} 3=N$. adrianii Petak 58, hutan alam Gunung Slamet, $\mathrm{G} 1=N$. gymnampora Petak 3 Bukit Tuban Gunung Bhisma, $\mathrm{G} 2=$ N. gymnampora Gunung Merbabu, G3 = N. gmnampora Gunung Prau Desa Pranten Kecamatan Bawang, $\mathrm{G} 4=$ N. gymnampora Petung Kriono Pekalongan, Dieng lereng utara). 


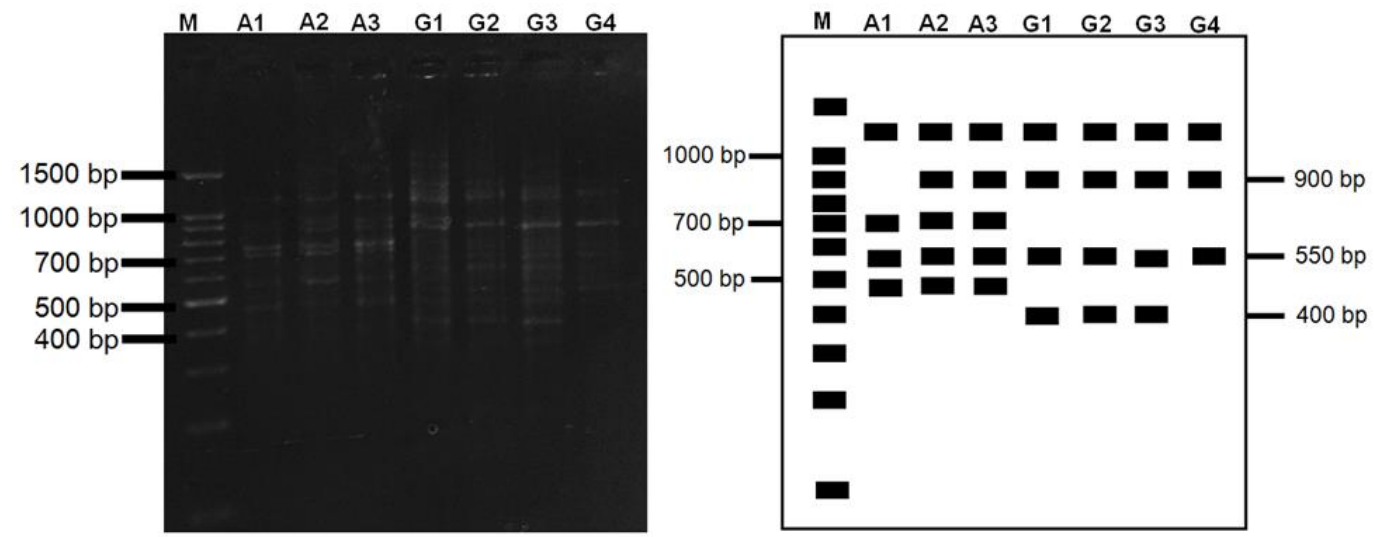

Gambar 3a dan 3b. Hasil dan interpretasi hasil amplifikasi PCR-RAPD menggunakan primer ES10A26 (M $=$ DNA marka $1 \mathrm{~kb}, \mathrm{~A} 1=N$. adrianii lgir Gowok, hutan lindung Baturraden, $\mathrm{A} 2=N$. adrianii hutan lindung Gunung Slamet, $\mathrm{A} 3=\mathrm{N}$. adrianii Petak 58, hutan alam Gunung Slamet, $\mathrm{G} 1=$ N. gymnampora Petak 3 Bukit Tuban Gunung Bhisma, G2 $=$ N. gymnampora Gunung Merbabu, G3 = N. gmnampora Gunung Prau Desa Pranten Kecamatan Bawang, G4 $=N$. gymnampora Petung Kriono Pekalongan, Dieng lereng utara).
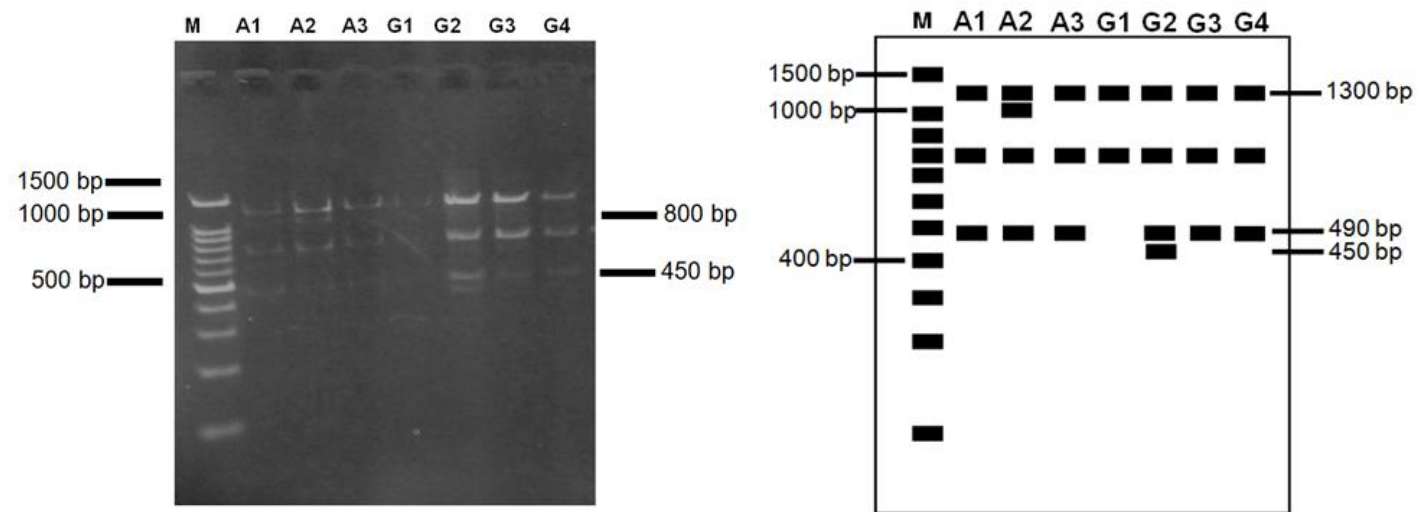

Gambar 4a dan 4b. Hasil daninterpretasi hasil amplifikasi PCR-RAPD menggunakan primer ES10C24 (M $=$ DNA marka $1 \mathrm{~kb}, \mathrm{~A} 1=N$. adrianii lgir Gowok, hutan lindung Baturraden, $\mathrm{A} 2=N$. adrianii hutan lindung Gunung Slamet, $\mathrm{A} 3=\mathrm{N}$. adrianii Petak 58, hutan alam Gunung Slamet, $\mathrm{G} 1=$ N. gymnampora Petak 3 Bukit Tuban Gunung Bhisma, G2 = N. gymnampora Gunung Merbabu, G3 $=$ N. gmnampora Gunung Prau Desa Pranten Kecamatan Bawang, G4 $=N$. gymnampora Petung Kriono Pekalongan, Dieng lereng utara).
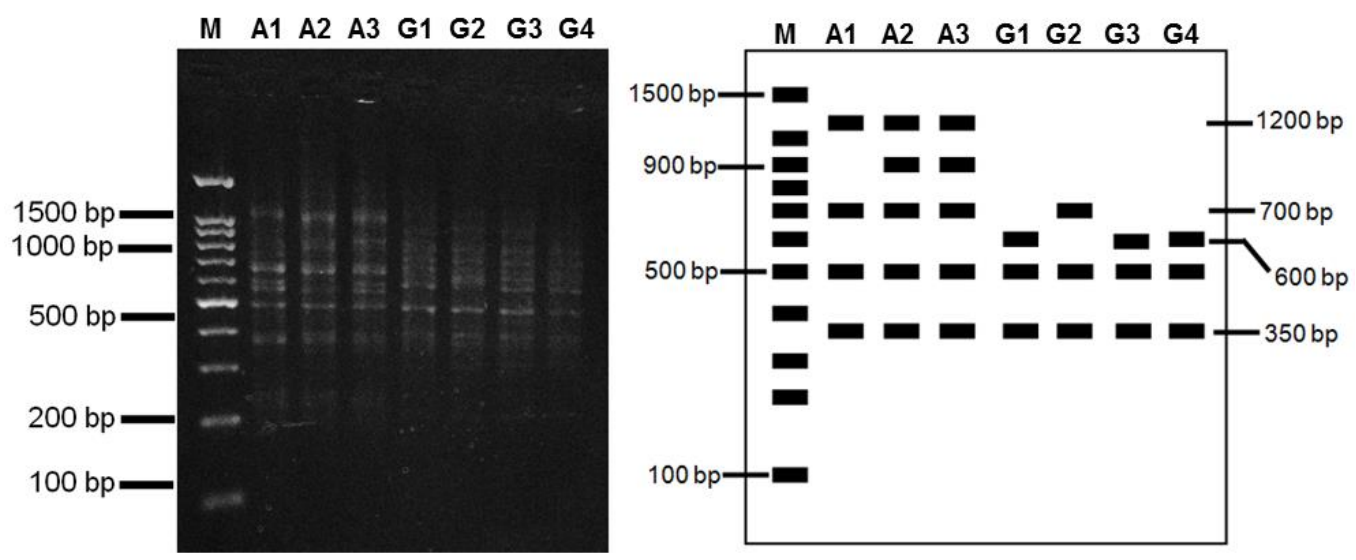

Gambar $5 a$ dan $5 b$. Hasil dan interpretasi hasil amplifikasi PCR-RAPD menggunakan primer ES10G33 $(\mathrm{M}=\mathrm{DNA}$ marka $1 \mathrm{~kb}, \mathrm{~A} 1=N$. adrianii Igir Gowok, hutan lindung Baturraden, $\mathrm{A} 2=N$. adrianii hutan lindung Gunung Slamet, $A 3=N$. adrianii Petak 58, hutan alam Gunung Slamet, G1 = N. gymnampora Petak 3 Bukit Tuban Gunung Bhisma, G2 = N. gymnampora Gunung Merbabu, G3 = N. gmnampora Gunung Prau Desa Pranten Kecamatan Bawang, $\mathrm{G} 4=$ N. gymnampora Petung Kriono Pekalongan, Dieng lereng utara). 


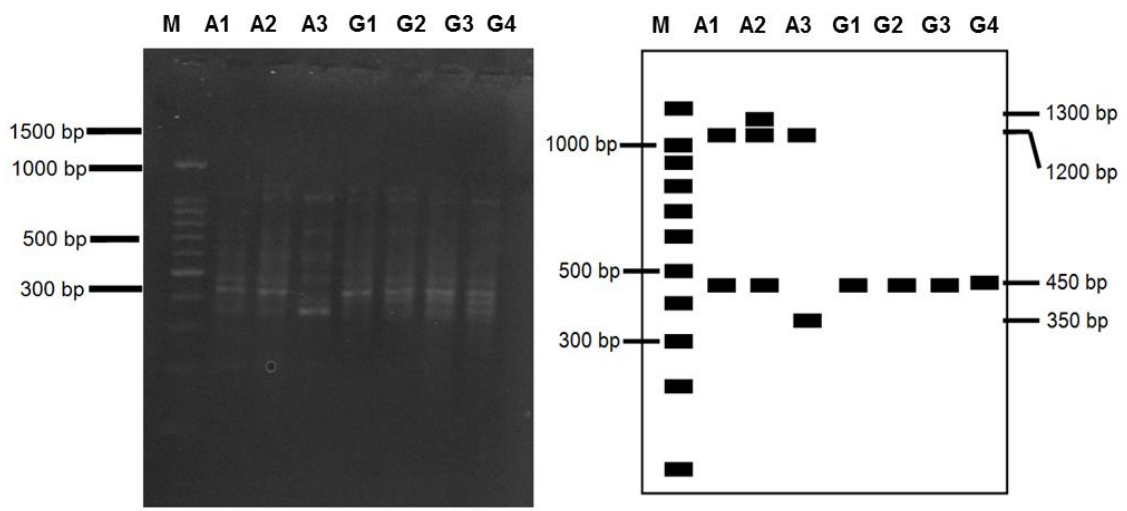

Gambar 6a dan 6b. Hasil daninterpretasi hasil amplifikasi PCR-RAPD menggunakan primer OPA-2 $(\mathrm{M}=$ DNA marka $1 \mathrm{~kb}, \mathrm{~A} 1=N$. adrianii Igir Gowok, hutan lindung Baturraden, $\mathrm{A} 2=N$. adrianii hutan lindung Gunung Slamet, $\mathrm{A} 3=N$. adrianiiPetak 58, hutan alam Gunung Slamet, $\mathrm{G} 1=N$. gymnampora Petak 3 Bukit Tuban Gunung Bhisma,G2= N. gymnampora Gunung Merbabu,G3= N. gmnampora Gunung Prau Desa Pranten Kecamatan Bawang,G4= N. gymnampora Petung Kriono Pekalongan, Dieng lereng utara).
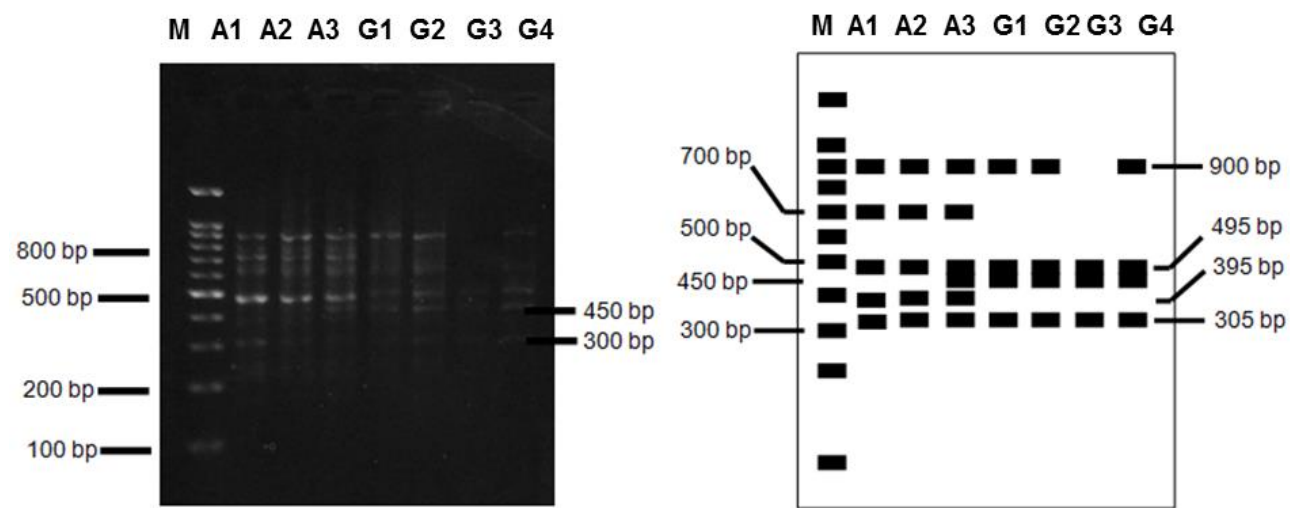

Gambar 7a dan 7b. Hasil daninterpretasi hasil amplifikasi PCR-RAPD menggunakan primer OPA-9 (M = DNA marka $1 \mathrm{~kb}, \mathrm{~A} 1=N$. adrianii Igir Gowok, hutan lindung Baturraden, $\mathrm{A} 2=N$. adrianii hutan lindung Gunung Slamet, $\mathrm{A} 3=N$. adrianiiPetak 58, hutan alam Gunung Slamet, $\mathrm{G} 1=N$. gymnampora Petak 3 Bukit Tuban Gunung Bhisma,G2 $=N$. gymnampora Gunung Merbabu,G3= N. gmnampora Gunung Prau Desa Pranten Kecamatan Bawang,G4= $N$. gymnampora Petung Kriono Pekalongan, Dieng lereng utara).
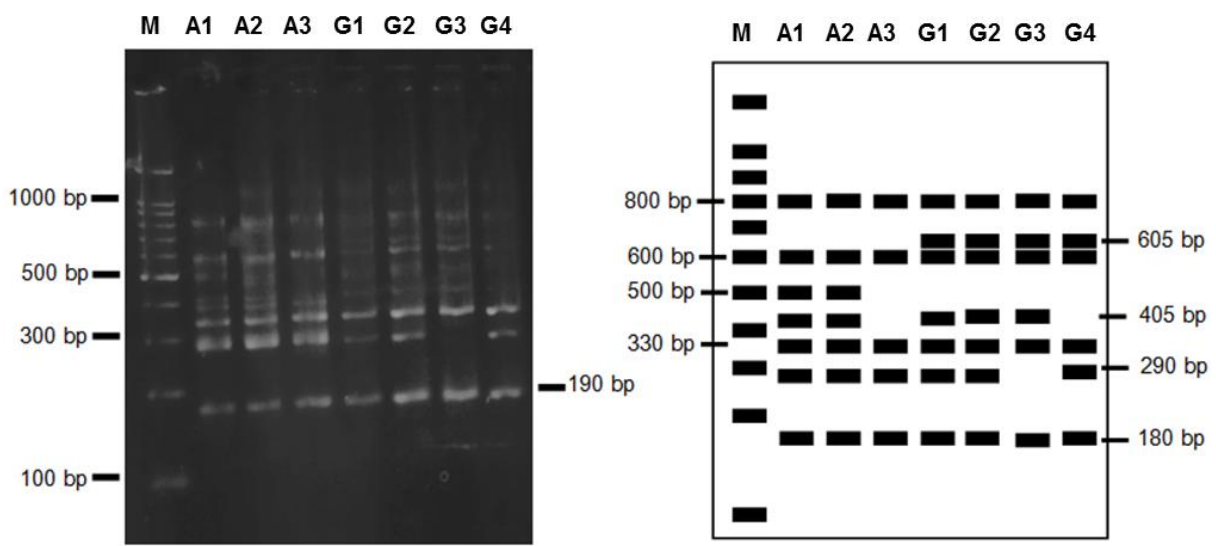

Gambar 8a dan 8b. Hasil daninterpretasi hasil amplifikasi PCR-RAPD menggunakan primer OPA-13 (M = DNA marka $1 \mathrm{~kb}, \mathrm{~A} 1=N$. adrianii Igir Gowok, hutan lindung Baturraden, $\mathrm{A} 2=N$. adrianii hutan lindung Gunung Slamet, $A 3=N$. adrianiiPetak 58, hutan alam Gunung Slamet, $G 1=N$. gymnampora Petak 3 Bukit Tuban Gunung Bhisma,G2= N. gymnampora Gunung Merbabu,G3= N. gmnampora Gunung Prau Desa Pranten Kecamatan Bawang,G4= N. gymnampora Petung Kriono Pekalongan, Dieng lereng utara). 
$\begin{array}{lllllllll}\text { M } & \text { A1 } & \text { A2 } & \text { A3 } & \text { G1 } & \text { G2 } & \text { G3 } & \text { G4 }\end{array}$

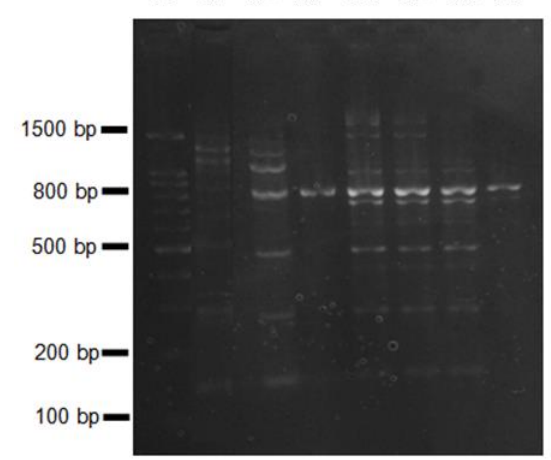

$\begin{array}{llllllllllllll}M & \text { A1 } & \text { A2 } & \text { A3 } & \text { G1 } & \text { G2 } & \text { G3 } & \text { G4 }\end{array}$

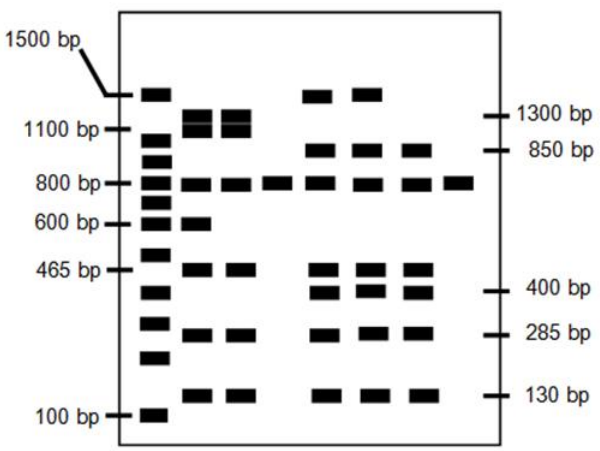

Gambar 9a dan 9b. Hasil daninterpretasi hasil amplifikasi PCR-RAPD menggunakan primer OPB-3 (M = DNA marka $1 \mathrm{~kb}, \mathrm{~A} 1=N$. adrianii Igir Gowok, hutan lindung Baturraden, $\mathrm{A} 2=N$. adrianii hutan lindung Gunung Slamet, $\mathrm{A} 3=N$. adrianiiPetak 58, hutan alam Gunung Slamet, $\mathrm{G} 1=N$. gymnampora Petak 3 Bukit Tuban Gunung Bhisma,G2= N. gymnampora Gunung Merbabu,G3= N. gmnampora Gunung Prau Desa Pranten Kecamatan Bawang,G4= $N$. gymnampora Petung Kriono Pekalongan, Dieng lereng utara).

$\begin{array}{lllllllll}\text { M } & \text { A1 } & \text { A2 } & \text { A3 } & \text { G1 } & \text { G2 } & \text { G3 } & \text { G4 }\end{array}$

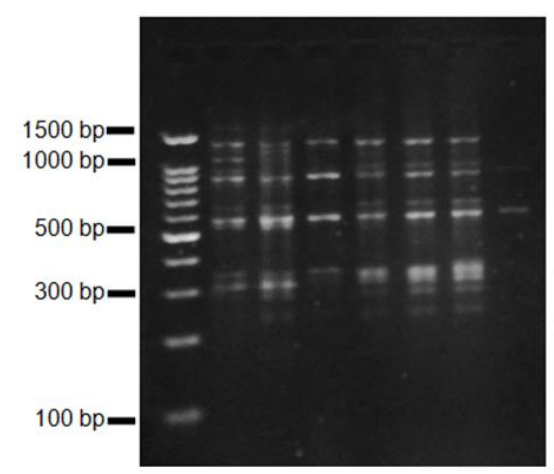

$\begin{array}{llllllll}M & \text { A1 } & \text { A2 } & \text { A3 } & \text { G1 } & \text { G2 } & \text { G3 } & \text { G4 }\end{array}$

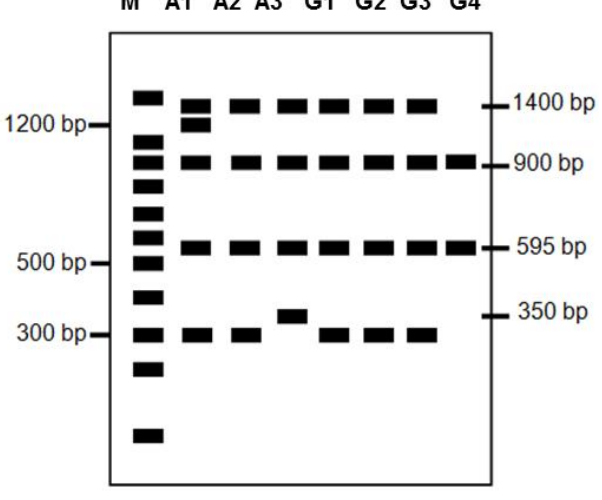

Gambar 10 a dan 10b. Hasil daninterpretasi hasil amplifikasi PCR-RAPD menggunakan primer OPB-5 (M $=$ DNA marka $1 \mathrm{~kb}, \mathrm{~A} 1=N$. adrianii Igir Gowok, hutan lindung Baturraden, $\mathrm{A} 2=N$. adrianii hutan lindung Gunung Slamet, $A 3=N$. adrianiiPetak 58, hutan alam Gunung Slamet, $G 1=N$. gymnampora Petak 3 Bukit Tuban Gunung Bhisma,G2= N. gymnampora Gunung Merbabu,G3= N. gmnampora Gunung Prau Desa Pranten Kecamatan Bawang,G4= N. gymnampora Petung Kriono Pekalongan, Dieng lereng utara).

$\begin{array}{lllllllll}M & \text { A1 } & \text { A2 } & \text { A3 } & \text { G1 } & \text { G2 } & \text { G3 } & \text { G4 }\end{array}$

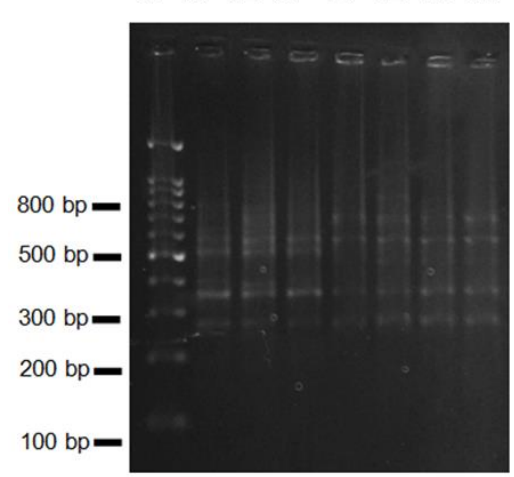

$\begin{array}{lllllllll}M & \text { A1 } & \text { A2 } & \text { A3 } & \text { G1 } & \text { G2 } & \text { G3 } & \text { G4 }\end{array}$

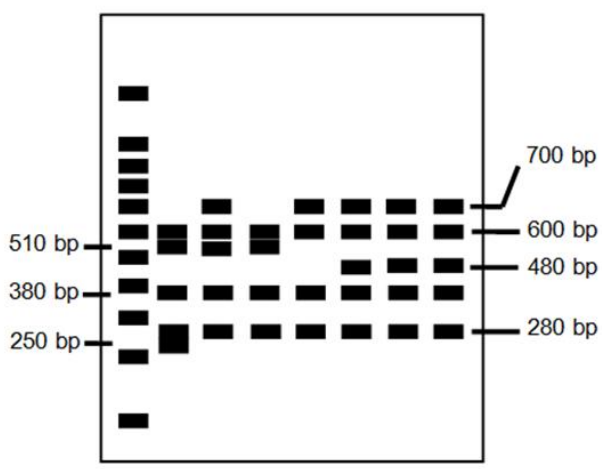

Gambar 11a dan 11b. Hasil daninterpretasi hasil amplifikasi PCR-RAPD menggunakan primer OPB-7 (M $=$ DNA marka $1 \mathrm{~kb}, \mathrm{~A} 1=N$. adrianii Igir Gowok, hutan lindung Baturraden, $\mathrm{A} 2=N$. adrianii hutan lindung Gunung Slamet, $A 3=N$. adrianiiPetak 58, hutan alam Gunung Slamet, $G 1=N$. gymnampora Petak 3 Bukit Tuban Gunung Bhisma,G2= N. gymnampora Gunung Merbabu,G3= N. gmnampora Gunung Prau Desa Pranten Kecamatan Bawang,G4= $N$. gymnampora Petung Kriono Pekalongan, Dieng lereng utara). 
Tabel 2. Polimorfisme hasil analisis RAPD pada kantung semar koleksi Kebun Raya Baturraden

\begin{tabular}{lccccc}
\hline \multicolumn{1}{c}{ Primer } & Sekuen (5'-3') & $\begin{array}{c}\text { Jumlah pita } \\
\text { polimorfik }\end{array}$ & $\begin{array}{c}\text { Jumlah pita } \\
\text { monomorfik }\end{array}$ & Total & $\begin{array}{c}\text { Panjang lokus } \\
\text { (bp) }\end{array}$ \\
\hline ES10G23 & GTAGGCGTCG & 2 & 4 & 6 & $300-1.500$ \\
ES10A24 & CAGGGGACGA & 5 & 1 & 6 & $400-1.200$ \\
ES10C26 & GGCTCGTACC & 3 & 2 & 5 & $450-1.300$ \\
ES10G33 & GGCTCGTACC & 4 & 2 & 6 & $500-1.300$ \\
OPA-2 & TGCCGAGCTG & 4 & 0 & 4 & $350-1.300$ \\
OPA-9 & GGGTAACGCC & 4 & 2 & 6 & $305-900$ \\
OPA-13 & CAGCACCCAC & 4 & 4 & 8 & $180-800$ \\
OPB-3 & CATCCCCCTG & 9 & 1 & 10 & $130-1.500$ \\
OPB-5 & TGCGCCCTTC & 4 & 2 & 6 & $300-1.400$ \\
OPB-7 & GGTGACGCAG & 4 & 3 & 7 & $250-700$ \\
Total & & $\mathbf{4 3}$ & $\mathbf{2 1}$ & $\mathbf{6 4}$ & \\
\hline
\end{tabular}

Hasil analisis polimorfisme terhadap sampel kantung semar koleksi Kebun Raya Baturraden secara keseluruhan mampu mendeteksi 43 pita polimorfik $(67,2 \%)$ dari total 64 pita yang teramplifikasi. Jumlah pita polimorfik yang dihasilkan rata-rata 4 pita per primer.Primer OPA-2 dan OPB-3 menghasilkan polimorfisme tertinggi, masing-masing $100 \%$ (4 dari 4 ) dan $90 \%$ (9 dari 10). Sementara itu, primer ES10G23 dan OPA-13 menghasilkan polimorfisme terendah, masing-masing 33\% (2 dari 6) dan 50\% (4 dari 8) (Tabel 2).

Penelitian RAPD sebelumnya menghasilkan tingkat polimorfisme yang berbedabeda. Nurhidayati (2016) mendeteksi keanekaragaman genetik kultivar duku dan memperoleh polimorfisme 96,96\%. Karsinah et al. (2002) mendapatkan polimorfisme pada jeruk sebesar 91,8\%. Azizah (2015) mendapatkan polimorfisme $90,4 \%$ pada kultivar ubi jalar. Nandariyah (2010) mendapatkan polimorfisme
$68,4 \%$ pada kultivar salak. Menurut Rout et al. (2003), tingkat polimorfisme yang diperoleh dapat digunakan sebagai indikator tinggi rendahnya keanekaragaman genetik.

\section{Analisis klaster N. adrianii dan $N$. gymnampora}

Nilai jarak (ketidaksamaan) genetik berkisar dari 0,780 hingga 0,438 dengan jarak tertinggi terdapat antara N. gymnampora "G3" dan N. adrianii "A3" (Tabel 3.). Sementara itu, jarak terendah terdapat di antara N. gymnampora "G2, G3", dan "G1".Menurut Nei dan Li (1987), jarak genetik yang besar menandakan bahwa hubungan kekerabatan genetik antarspesies atau pun antarkultivar cukup jauh.Sebaliknya, jarak genetik yang kecil menandakan hubungan kekerabatan genetik yang dekat.

Tabel 3. Hasil analisis jarak genetik antara N. adrianii dan N. gymnamporakoleksi Kebun Raya Baturaden

\begin{tabular}{cccccccc}
\hline & A1 & A2 & A3 & G1 & G2 & G3 & G4 \\
\hline A1 & $* *$ & & & & & & \\
A2 & 0,125 & $* *$ & & & & & \\
A3 & 0,297 & 0,266 & $* *$ & & & & \\
G1 & 0,406 & 0,375 & 0,422 & $* *$ & & & \\
G2 & 0,391 & 0,359 & 0,406 & $\mathbf{0 , 0 7 8}$ & $* *$ & & \\
G3 & 0,422 & 0,391 & $\mathbf{0 , 4 3 8}$ & $\mathbf{0 , 0 7 8}$ & 0,094 & $* *$ & \\
G4 & 0,172 & 0,266 & 0,406 & 0,234 & 0,281 & 0,250 & $* *$
\end{tabular}

$\mathbf{A} 1=N$. adrianii Igir Gowok, hutan lindung Baturraden, $\mathbf{A} 2=N$. adrianii hutan lindung Gunung Slamet, $\mathbf{A} 3=N$. adrianii Petak 58, hutan alam Gunung Slamet, G1 = N. gymnampora Petak 3 Bukit Tuban Gunung Bhisma, G2 = N. gymnampora Gunung Merbabu, G3 = N. gymnampora Gunung Prau Desa Pranten Kecamatan Bawang, G4 = N. gymnampora Petung Kriono Pekalongan, Dieng lereng utara. 


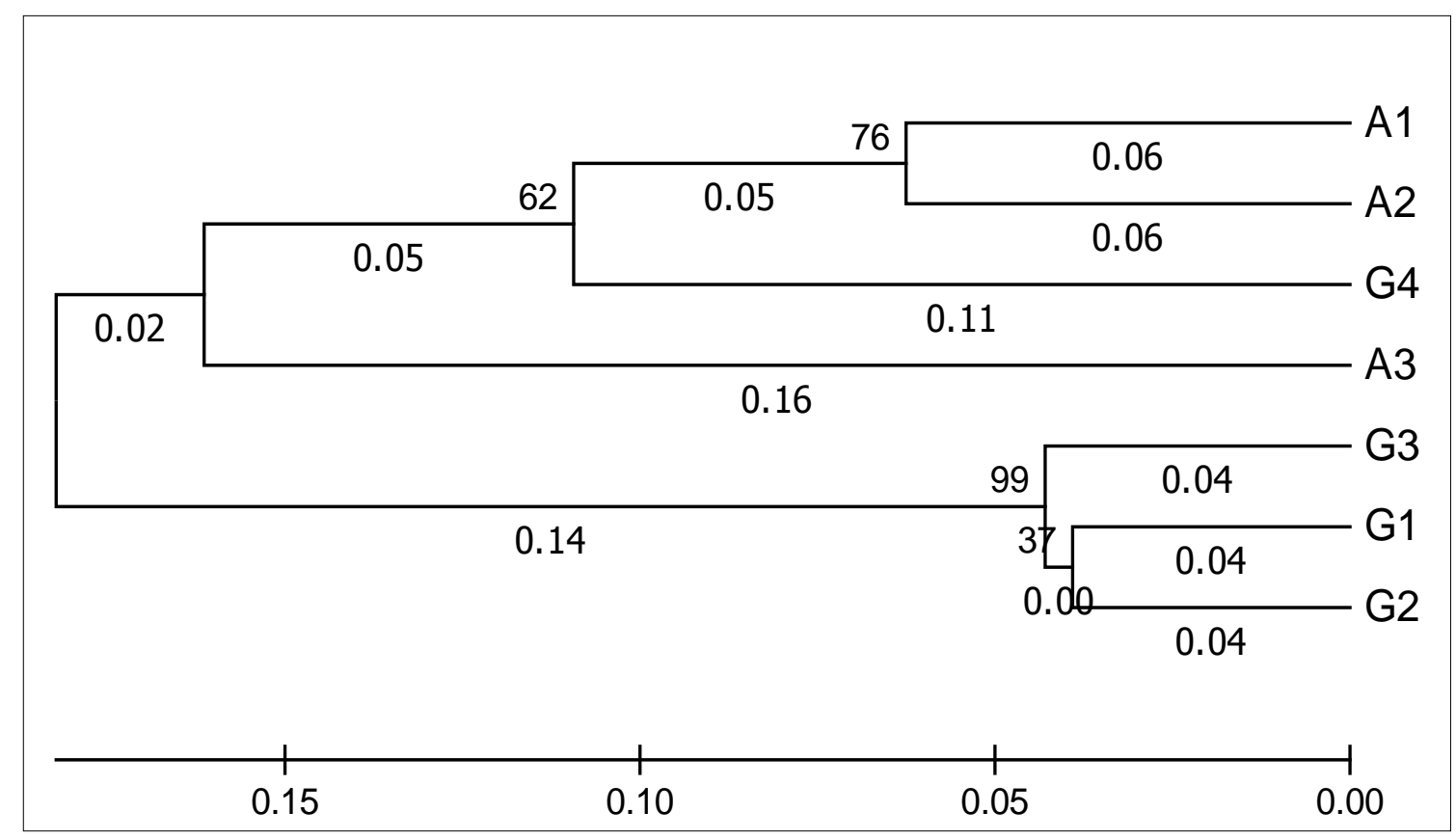

Gambar 12. Dendogram kekerabatan antara N. adrianii dan N. gymnamporakoleksi Kebun Raya Baturraden.

Nilai jarak genetik yang diperoleh kemudian digunakan untuk untuk mengonstruksi dendogram bagi ketujuh sampel kantung semar koleksi Kebun Raya Baturraden.Berdasarkan dendogram yang terbentuk, semua genotipe dapat dibedakan antara satu dan lainnya. Apabila ditarik garis lurus yang memotong dendogram pada jarak genetik $18 \%$, maka terlihat adanya dua klaster, yaitu klaster I yang terdiri atas $N$. adrianii 'A1', 'A2', 'A3', N. gymnampora 'G4'dan klaster II yang terdiri atas N. gymnampora 'G1', 'G2','G3'. Klaster I terbagi menjadi dua subklaster yang memisahkan antara 'A3' pada subklaster 1 dan 'A1', 'A2', 'G4' pada subklaster 2. Sementara itu, klaster II juga terbagi menjadi dua subklaster, yaitu subklaster 1 yang terdiri atas 'G3'dan subklaster 2 yang terdiri atas 'G1' dan 'G2'.

Anggota masing-masing klaster memiliki kecenderungan untuk mengelompok berdasarkan letak geografinya. Anggota klaster I terdiri atas $N$. adrianii dari Igir Gowok hutan lindung Baturraden (1.200 m dpl), dari hutan lindung Gunung Slamet (1.410 m dpl), dan dari Petak 58 hutan alam Gunung Slamet $(1.139 \mathrm{~m} \mathrm{dpl})$, yang semuanya termasuk dalam subklaster 1. Sementara itu, pada subklaster 2 terdapat $N$. gymnampora yang berasal dari Petung Kriono Pekalongan, Dieng lereng utara $(1.755 \mathrm{~m} \mathrm{dpl})$.Pada klaster II semua sampel terdiri atas N. gymnampora, masingmasing berasal dari Gunung Prau Desa Pranten Kecamatan Bawang (1.680 m dpl), Petak 3 Bukit Tuban Gunung Bhisma (1.563 m dpl), dan Gunung Merbabu (1.951 m dpl).Semua sampel merupakan koleksi Kebun Raya Baturraden.Dalam hal ini, $N$. adrianii merupakan spesies semiendemik Gunung Slamet, sedangkan $N$. gymnampora merupakan spesies endemik Jawa Tengah. Song et al., (2000) melaporkan pengelompokan spesies duku berdasarkan marka RAPD yang ternyata juga sesuai dengan letak geografi.

Sampel 'A1' dan 'A3' terpisah jauh dalam subklaster yang berbeda. Pada lokus tertentu 'A1' menghasilkan pita, sedangkan 'A3' tidak menghasilkan pita, dan begitu juga sebaliknya, pada lokus yang lain. Dengan demikian, $N$. adrianii 'A1' dan 'A3' terpisah karena banyaknya perbedaan kemunculan pita RAPD.N. gymnampora "G3" pada klaster II juga terlihat terpisah dari N. gymnapora "G4" yang terletak pada klaster I.

\section{Simpulan}

Berdasarkan hasil dan pembahasan tersebut di atas dapat diambil kesimpulan bahwa primer OPA-2 dan OPB-3 menghasilkan polimorfisme tertinggi, sedangkan primer ES10G23 dan OPA-13 menghasilkan polimorfisme terendah.Terdapat dua klaster kantung semar koleksi Kebun Raya Baturraden yang cenderung terpisah berdasarkan posisi geografi. 


\section{Daftar Referensi}

Azizah, E. 2015.Analisis Kekerabatan Beberapa Kultivar Ubi Jalar (Ipomoea batatas L.) berdasarkan Penanda RAPD.Skripsi. Universitas Jenderal Soedirman, Purwokerto.

Berita Negara Republik Indonesia Nomor 51 2008. Peraturan Menteri Kehutanan Nomor: P. 57/Menhut-II/2008 Tentang Arahan Strategis Konservasi Species Nasional 2008-2018.

Doyle, J.J. \& Doyle, J.L. 1990.Isolation of plant DNA from fresh tissue.Focus 12(1): 13 15.

Karsinah, Sudarsono, Setyobudi, L. \& Aswidinnoor, H. 2001.Keragaman genetik plasma nutfah jeruk berdasarkan analisis penanda RAPD.Jurnal Bioteknologi Pertanian 7(1): 8 - 16.

Nandariyah. 2010. Morphology and RAPS (Random Amplified Polymorphic DNA) based classification of genetik variability of Java salacca (Salacca zalazza Gaertner. Voss). Journal of Biotechnology and Biodiversity 1(1): 8 - 13.

Nei, M. \& Li, W. 1987.Estimation of average heterozygosity and genetik distance from a small number of individual. Genetics 89: 583 -590 .

Nurhidayati, R,W. 2016. Keragaman Genetik Kultivar Duku (Lansium parasiyicum) K.C.
Sahni \& Bennet) di Purbalingga berdasarkan Penanda RAPD.Skripsi. Universitas Jenderal Soedirman, Purwokerto.

Puspitaningtyas, D.M. \& Wawangningrum, H. 2007. Keragaman Nepenthes di suaka alam Sulasih Talang-Sumatera Barat. Biodiversitas 8(2): 152 - 156.

Rout, G R., Bhatacharya, D., Nanda, R M., Nayak, S., \& Das, P. 2003. Evaluation of genetic relationship in Dalbergia species using RAPD markers. Bioconservation 12: 197 206.

Song, B.K., Clyde, M.M., Wickneswari, R, \&Norman, M.N. 2000. Genetic relatedness among Lansium domesticum accessions using RAPD markers. Annals of Botany 8: $299-307$

Tamura, K., Peterson, D., Peterson, N., Stecher, G., Nei, M., Kumar, S. 2011. MEGA5: Molecular Evolutionary Genetics Analysis using Maximum Likelihood, Evolutionary Distance, and Maximum Parsimony Methods. Mol. Biol. Evol. 28: 2731 - 2739.

Williams, J.G.K., Kubelik, A.R., Livak, K.J., Rafalski, J.A., \& Tingey, S.V.1990. DNA polymorphisms amplified by arbitrary primers are useful as genetic markers.Nucleid Acids Research 18: 125 130. 